\title{
Variations in seep mussel bed communities along physical and chemical environmental gradients
}

\author{
Derk C. Bergquist ${ }^{1,3, *}$, Clint Fleckenstein ${ }^{1}$, Julie Knisel ${ }^{1}$, Brett Begley ${ }^{1}$, \\ Ian R. MacDonald ${ }^{2}$, Charles R. Fisher ${ }^{1}$ \\ ${ }^{1}$ Department of Biology, Pennsylvania State University, 208 Mueller Laboratory, University Park, Pennsylvania 16802, USA \\ ${ }^{2}$ Physical and Life Sciences Department, Texas A\&M University - Corpus Christi, 6300 Ocean Dr. ST320, Corpus Christi, \\ Texas 78412, USA \\ ${ }^{3}$ Present address: Department of Zoology, University of Florida, 223 Bartram Hall, Gainesville, Florida 32611-8525, USA
}

\begin{abstract}
This study examined the faunal communities associated with beds of the hydrocarbon seep mussel Bathymodiolus childressi in the Gulf of Mexico and the relationships between these communities and local environmental characteristics. Mussels, their associated fauna and accompanying water chemistry parameters were collected at 17 locations across 4 hydrocarbon seep sites. A total of 19 species, mostly seep endemics, were identified. Species richness and fauna density were significantly and negatively correlated with methane concentration and were significantly and positively correlated with oxygen concentration. Canonical Correspondence Analysis (CCA) separated polychaetes, alvinocarid shrimp and gastropods along gradients of methane and oxygen concentrations. Polychaetes and alvinocarid shrimp tended towards lower oxygen and higher methane concentrations and gastropods tended towards higher oxygen and lower methane. The larger-sized predaceous gastropods and decapods were associated with lower sulfide and higher oxygen concentrations. The proportion of the community comprising of endemic species was significantly and positively correlated with mussel biomass and shell surface area. Other measures of habitat complexity (mussel density, shell surface area and biomass) explained little of the variation in the associated faunal communities. The results suggest that oxygen and methane availabilities play a substantial role in structuring these communities with several dominant seep heterotrophs partitioning resources among different microenvironments.
\end{abstract}

KEY WORDS: Benthic community $\cdot$ Chemical gradient $\cdot$ Habitat complexity $\cdot$ Bathymodiolus childressi · Cold seep

\section{INTRODUCTION}

Hydrothermal vents and cold seeps host highdensity communities that contrast sharply with the surrounding sparsely populated deep-sea floor (Tunnicliffe 1991, Sibuet \& Olu 1998). Production, driven by bacterial chemoautotrophy, provides the nutrition necessary to support the high biomass associated with vent and seep systems (Fisher 1996). Sessile invertebrates, such as vestimentiferan tubeworms, bathymodiolid mussels and vesicomyid clams that are dependent upon chemoautotrophic bacterial symbionts for nutrition, typically dominate vent and seep communities (Childress \& Fisher 1992). The physical structures created by these symbiontbearing invertebrates in turn provide habitat for a diverse array of heterotrophic fauna including gastropods, polychaetes, decapods, and fish (Sarrazin \& Juniper 1999, Van Dover \& Trask 2000, Bergquist et al. 2003).

At cold hydrocarbon seeps on the upper Louisiana slope (ULS) of the Gulf of Mexico, the mussel Bathymodiolus childressi represents one of the most numerous and widespread of the symbiont-bearing, 
structure-forming invertebrates. B. childressi obtains the bulk of its nutrition from methanotrophic symbionts housed within its gills (Childress et al. 1986, Cary et al. 1988, Streams et al. 1997) and inhabits areas of relatively vigorous seepage (Nix et al. 1995). These habitats are generally characterized by high methane concentrations, low oxygen concentrations, and occasionally abundant crude oil and hydrogen sulfide (Smith et al. 2000, Bergquist et al. 2004). However, the chemical environments and characteristics of the resident mussels tend to differ substantially among different seep sites and mussel beds within a seep site. Mussel beds located in areas dominated by petroleum seepage (MacDonald 1998) tend to be characterized by low methane and high sulfide concentrations, abundant crude oil, and mussels with a relatively slow growth rate and poor physiological condition (Nix et al. 1995, Bergquist et al. 2004). Mussel beds located in seep sites dominated by brine (MacDonald 1998) tend to be characterized by higher methane and lower sulfide concentrations, little crude oil and by mussels with a relatively faster growth rate and better physiological condition (Smith et al. 2000, Bergquist et al. 2004). Within seep sites, all these characteristics tend to vary substantially among mussel beds and can vary among different portions of a single mussel bed. For example, at one well studied brine-dominated site (Brine Pool NR 1), a single large mussel bed encircles a pool of supersaturated brine (MacDonald et al. 1990). The inner edge of the mussel bed is broadly characterized by high methane and low sulfide concentrations, supporting smaller mussels with a fast growth rate. The outer edge of the mussel bed is characterized by lower methane and higher sulfide concentrations, supporting larger mussels with a slower growth rate (Smith et al. 2000). Thus, the shell matrices of $B$. childressi beds represent a wide range of habitat characteristics, but the relationships between the resident fauna and the physical, biological and chemical characteristics of these mussel beds have not been examined.

Carney (1995) reported that the fauna associated with beds of Bathymodiolus childressi are dominated by detritivorous gastropods, polychaetes and crustaceans and tend to be homogenous in composition among different mussel beds even those separated by tens of kilometers. Unfortunately, the collections in that study were not quantitative and accompanying environmental characteristics were not determined. The goals of the current study are: (1) to characterize the communities associated with beds of $B$. childressi on the ULS, and (2) to determine whether these communities vary with local environmental characteristics.

\section{MATERIALS AND METHODS}

Site descriptions. During July and August of 1995 and 1997, mussel beds were sampled at 4 geographically distinct sites within the Minerals Management Service (MMS) Green Canyon and Garden Banks leasing blocks on the ULS of the Gulf of Mexico (Fig. 1). Two sites characterized by pooled hypersaline fluids that were saturated with methane were designated 'brine' sites, and 2 sites characterized by an abundance of hydrocarbons in sediments near the seafloor were designated 'petroleum' sites. The first brine site, Brine Pool NR1 (BP), was located at $27^{\circ} 43^{\prime} 24^{\prime \prime} \mathrm{N}$, $91^{\circ} 16^{\prime} 30^{\prime \prime} \mathrm{W}$ and at a depth of $650 \mathrm{~m}$ within the MMS Green Canyon leasing block 233. The site was characterized by a single large pool of brine $22 \mathrm{~m}$ in length and $11 \mathrm{~m}$ wide, with salinity levels of $120 \mathrm{~g} \mathrm{~kg}^{-1}$. The pool was surrounded by a single continuous mussel bed (Bathymodiolus childressi), varying in width from 3 to $7 \mathrm{~m}$ and covering an area of $\sim 540 \mathrm{~m}^{2}$ (MacDonald et al. 1990). The mussel bed was divided into 2 visibly distinct zones: inner and outer. The inner edge was characterized by an abundance of smaller mussels at high densities. The outer edge was predominately large individuals occurring at lower densities with numerous disarticulated shells (Smith et al. 2000). The second brine site (GB) was located at $27^{\circ} 37^{\prime} \mathrm{N}$, $92^{\circ} 11^{\prime} \mathrm{W}$ and at a depth of $\sim 670 \mathrm{~m}$ within the MMS Garden Banks leasing block 425 (MacDonald et al. 2000). This site supported a patchy distribution of high-density mussel beds, with very few vestimentiferans. Unlike BP, this site did not have a distinct, welldeveloped brine pool but was characterized by brine saturated (133 $\mathrm{g} \mathrm{kg}^{-1}$ ), almost liquid sediments (MacDonald 1998).

The first petroleum site, Bush Hill $(\mathrm{BH})$ was located at $27^{\circ} 47^{\prime} \mathrm{N}, 91^{\circ} 30^{\prime} 24^{\prime \prime} \mathrm{W}$ at a depth of 540 to $580 \mathrm{~m}$ at

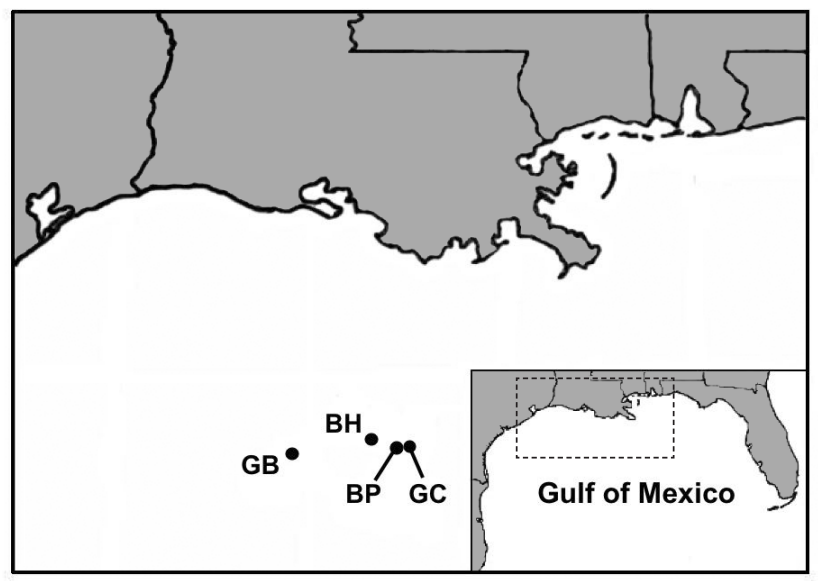

Fig. 1. Locations of the 4 study sites on the upper Louisiana slope (ULS) of the Gulf of Mexico 
the border of the MMS Green Canyon leasing blocks 184 and 185 (Brooks et al. 1989, MacDonald et al. 1989). The main portion of $\mathrm{BH}\left(\sim 10000 \mathrm{~m}^{2}\right)$ supported a large number of vestimentiferan tubeworm assemblages and numerous mussel beds ranging in size from 1 to $20 \mathrm{~m}^{2}$. Additional scattered mussel beds and tubeworm clumps were found in the $120000 \mathrm{~m}^{2}$ area surrounding the main site. The second petroleum site (GC) was located at $27^{\circ} 44.7^{\prime} \mathrm{N}, 91^{\circ} 13.3^{\prime} \mathrm{W}$, at a depth of $\sim 540 \mathrm{~m}$ within the MMS Green Canyon leasing block 234 (Brooks et al. 1989). Seep fauna at GC occured over an area of several square kilometers, and the central portion of this site supported an abundance of very large vestimentiferan aggregations and numerous mussel beds. Actively bubbling methane has commonly been observed in these mussel beds and much of the sediment was oil stained. Methane hydrates breached the seafloor in several locations at both of these petroleum sites (MacDonald et al. 2003).

Water sampling and analysis. Water among mussel beds from each of the 4 sites was sampled using the Johnson Sea Link II manned submersible (Harbor Branch Oceanographic Institution). Prior to the animal collections in each bed, 3 to 5 water samples were collected within the beds, $2.5 \mathrm{~cm}$ beneath the top surface of the mussel shells, using equipment and methodology described by Nix et al. (1995) and Smith et al. (2000). Samples were drawn into syringes primed with a zinc acetate solution (4:1 $0.12 \mathrm{M}$ zinc acetate: $1.5 \mathrm{M}$ $\mathrm{NaOH}$ ), which prevented the oxidation of sulfide in the sample by forming zinc sulfide (Gilboa-Garber 1971). All samples were acidified to release the sulfide and processed using a modified gas chromatograph that allowed the simultaneous quantification of methane, total sulfide (the sum of $\mathrm{S}^{2-}, \mathrm{HS}^{-}$, and $\mathrm{H}_{2} \mathrm{~S}$ ) and oxygen (Childress et al. 1984) on board the ship. Due to impurities in the carrier gas used in 1997, absolute concentrations of oxygen and sulfide were unreliable. These values should be internally consistent as they were all obtained using the same carrier gas.

Fauna collections. Following the completion of water sampling, mussels were collected by placing a stainless steel ring, measuring $23 \mathrm{~cm}$ on all sides, in a position that the submersible pilot judged to be representative of the mussel bed, amenable to collection, and undisturbed (Smith et al. 2000). In 1995, a round ring with a collection area of $0.196 \mathrm{~m}^{2}$ was employed, and in 1997 a square 'ring' with a collection area of $0.164 \mathrm{~m}^{2}$ was employed. Once the ring were positioned, all mussels and fauna within them were collected by scooping them into a temperature-insulated box on the front of the submersible. A suction device was then used to ensure all remaining contents within the ring were collected. In order to record any fauna that may have escaped collection, the entire process was observed by a scientist in the submersible and documented using a video camera.

In total, 17 collections were made using this methodology. One collection was made at each of the 4 different mussel beds at BH (1997), 1 at each of 2 different mussel beds at GC (1997), 1 at a single mussel bed at GB (1997) and 10 from the single continuous mussel bed at BP (6 in 1995 and 4 in 1997). At BP in 1995, 2 collections were made along the inner edge, 2 along the outer edge and 2 in the middle of the single large mussel bed encircling the pool of brine. In 1997, the corners of the square 'ring' forced the mussels and their associated fauna beneath the surface of the underlying brine, compromising our ability to collect all of the organisms. As a result of this, we have only reported the habitat and community characteristics for these 4 collections and have not included them in the formal analyses.

The contents of the collection box were poured through a $2 \mathrm{~mm}$ sieve and the fauna were separated from the retained debris on board the ship. The shell length of each mussel was measured using calipers, and a sub-sample of 6 to 12 mussels were prepared from each collection for later determination of shell surface area and tissue mass. The shell of each subsampled individual was carefully prised open, its adductor mussels were cut and the remaining tissue was then scraped into a pre-weighed sample bag. These samples were stored at $-20^{\circ} \mathrm{C}$, transported to the lab and stored at $-70^{\circ} \mathrm{C}$. The shells were cleaned, dried and labeled for later determination of shell surface area. The remaining (non-mussel) fauna were preserved in $7 \%$ formalin.

In the lab, mussel tissue ash-free dry weight (AFDW) was determined for each individual in order to derive an equation relating individual mass to shell length. We removed all solid tissue from the sample bag and homogenized it using stainless steel scalpels. Three sub-samples of the tissue homogenate were weighed wet, dried to a constant mass at $60^{\circ} \mathrm{C}$ (approximately $48 \mathrm{~h}$ ), weighed dry, then ashed at $500^{\circ} \mathrm{C}$ to obtain an AFDW. These samples were used to derive a wet weight to AFDW conversion factor for each individual. The total AFDW of solid tissue for each individual was then calculated from the total wet weight of its original homogenate and its individually derived conversion factor. Additional sub-samples of the internal fluids remaining in the sample bag were processed as described above for the solid tissue. Total individual tissue mass was then calculated as the sum of total solid tissue AFDW and total internal fluid AFDW. Because the relationship between AFDW and shell length is known to vary between mussel beds (Bergquist et al. 2004) an equation predicting mass from shell length was derived for each collection individually. 
Surface area of mussel shells (SA) was calculated by applying the empirically determined relationship between the mass of aluminum foil required to cover the outer surface of a mussel shell and the length of the shell. Thirty mussel shells, representative of the typical size range found at the sites, were used to derive this relationship. The outer surfaces of the mussel shells were carefully wrapped with stock aluminum foil paying special attention to avoid overlapping any regions, and the foil was trimmed around the perimeter of the shells. The mass of the aluminum foil was converted to surface area using the known mass of the stock aluminum foil $\left(0.00597 \mathrm{~g} \mathrm{~cm}^{-2}\right)$. The relationship between SA and shell length was determined by plotting the natural logarithm of the surface area against the natural logarithm of length to obtain an equation of the form $\mathrm{SA}=a \times$ length where $a$ and $b$ are constants derived through linear regression. This mathematical relationship was then applied to all of the mussels in each collection, and the estimated individual surface areas were summed to obtain a total shell surface area for each collection.

The associated fauna collections were transferred from the $7 \%$ formalin solution to $70 \%$ ethanol. The collections were sorted, identified to the lowest taxonomic affinity possible and counted. Species richness, species evenness $\left(J^{\prime}\right)$ and Shannon-Weiner diversity $\left(H^{\prime}\right)$ were calculated for each collection. Where possible, the residency status (endemic versus nonendemic) of each species was determined. For the purposes of this study, 'endemic' refers to those species known only from seep sites, while 'non-endemic' refers to those species known from the background fauna of the ULS. Associated fauna abundances were standardized to densities $\mathrm{m}^{-2}$.

Statistical analyses. Species effort curves were constructed using EstimateS software package (Colwell 2004) with cumulative bottom sampling area $\left(0.196 \mathrm{~m}^{2}\right.$ per sample) and cumulative number of individuals as measures of effort. Total species richness was extrapolated for BP and BH using the Incidence-based Coverage Estimator (ICE) as it tends to provide more consistent estimates than other techniques when the number of samples is small (Chazdon et al 1998). Spearman's rank correlations were used to compare community characteristics (species richness, evenness and diversity, fauna density and proportion of endemics) with mussel habitat characteristics (mussel density, shell surface area and biomass and oxygen, methane and sulfide concentration). Canonical Correspondence Analysis (CCA) was used to analyze species distributions among the different collections (PC-ORD for Windows 4.0, MjM Software). The species abundance table (standardized fauna densities) was used as the main matrix (13 collections $\times 19$ species). Environmental dissolved gas concentrations were log-transformed
(Palmer 1993) and were then combined with mussel density, shell surface area and biomass to form the second matrix (13 collections $\times 6$ parameters). Site scores were centered and normalized to a mean of zero and a variance of 1. Collections from BP in 1997 were not included in either the Spearman's rank correlation or CCA analyses.

\section{RESULTS AND DISCUSSION}

A total of 19 species were identified in the 17 collections made here (see Appendix 1). Thirteen species were found in 10 collections at BP (8 in 1995, 11 in 1997), 12 species were found in 4 collections at $\mathrm{BH}, 11$ species in 2 collections at GC and 6 species in 1 collection at GB. In general, species richness and overall fauna density in individual collections tended to be lower at brine sites than at petroleum sites (Table 1). The shape of the species effort curves suggests that species accumulation would continue relatively quickly with additional sampling overall, but that at the 2 most heavily sampled sites (BH and BP) additional sampling would result in the accumulation of only a few new species (Fig. 2). At BP, the first sample yielded an average of 4.7 species with the 5 additional samples adding only 3 more species. At $\mathrm{BH}$, at least 1 species was added up to the fourth sample. Estimates of total species richness based on ICE indicate that BP supported approximately 11 species, while BH supported approximately 17 species. The 4 samples taken at BP in 1997 yielded 11 species suggesting the estimate of total species richness is an underestimate for this site. Species accumulation curves approach the asymptote rapidly in hydrothermal vent mussel beds as well (Van Dover 2002). In general, this reflects a vent/seep fauna composed of a relatively small number of widely distributed species.

BP was dominated by polychaetes, particularly the endemic orbiniid Methanoaricia dendrobranchiata, while $\mathrm{BH}$ was dominated by small endemic grazing gastropods such as Bathynerita naticoidea and Provanna sculpta (Table 2). B. naticoidea was present at all sites, accounting for between 8.4 and $63.9 \%$ of the individuals collected. The endemic shrimp Alvinocaris stactophila dominated the crustacean fauna, accounting for at least $11.8 \%$ of the individuals at each site and was more dominant at brine sites than at petroleum sites (Table 2). The 4 most abundant species at each site accounted for at least $94.5 \%$ of all the individuals at that site. Seep endemic species dominated the fauna living amongst the mussel shells, accounting for $100 \%$ of all species and individuals that could be assigned an endemic/non-endemic status in most collections (Table 1). The extent of endemicity amongst the fauna 
Table 1. Characteristics of the communities associated with cold seep mussel beds. Bold numbers represent means for site characteristics. Numbers in parentheses indicate number of species for which seep endemic/non-endemic status was known

\begin{tabular}{|c|c|c|c|c|c|c|c|c|}
\hline \multirow[t]{2}{*}{ Site } & \multirow[t]{2}{*}{ No. } & \multirow[t]{2}{*}{ Position } & \multirow{2}{*}{$\begin{array}{l}\text { Species } \\
\text { richness }\end{array}$} & \multirow{2}{*}{$\begin{array}{c}\text { Fauna } \\
\text { density } \\
\left(\text { no. } \mathrm{m}^{2}\right)\end{array}$} & \multirow{2}{*}{$\begin{array}{c}\text { Species } \\
\text { evenness } \\
\left(J^{\prime}\right)\end{array}$} & \multirow{2}{*}{$\begin{array}{c}\text { Species } \\
\text { diversity } \\
\quad\left(H^{\prime}\right)\end{array}$} & \multicolumn{2}{|c|}{ Percent endemic } \\
\hline & & & & & & & Species & Individuals \\
\hline \multicolumn{9}{|l|}{1995} \\
\hline \multirow[t]{7}{*}{ BP } & 1 & Inner & 5 & 1482 & 0.52 & 0.83 & $100(4)$ & 100 \\
\hline & 2 & Inner & 5 & 845 & 0.36 & 0.59 & $100(5)$ & 100 \\
\hline & 3 & Middle & 4 & 234 & 0.65 & 0.90 & $100(4)$ & 100 \\
\hline & 4 & Middle & 5 & 815 & 0.31 & 0.49 & $100(5)$ & 100 \\
\hline & 5 & Outer & 3 & 418 & 0.84 & 0.92 & $100(3)$ & 100 \\
\hline & 6 & Outer & 6 & 331 & 0.41 & 0.73 & 80 (5) & 98 \\
\hline & & & 5 & 688 & 0.61 & 0.74 & 97 & 100 \\
\hline \multicolumn{9}{|l|}{1997} \\
\hline \multirow[t]{5}{*}{ BP } & 7 & Inner & 6 & 1693 & 0.41 & 0.74 & $100(5)$ & 100 \\
\hline & 8 & Inner & 7 & 312 & 0.73 & 1.42 & 60 (5) & 90 \\
\hline & 9 & Middle & 4 & 318 & 0.68 & 0.94 & $100(3)$ & 100 \\
\hline & 10 & Outer & 4 & 324 & 0.37 & 0.52 & $75(4)$ & 98 \\
\hline & & & 5 & 662 & 0.55 & 0.91 & 84 & 97 \\
\hline GB & 1 & & 6 & 709 & 0.50 & 0.90 & 100 & 100 \\
\hline \multirow[t]{5}{*}{$\mathrm{BH}$} & 1 & & 6 & 1559 & 0.58 & 1.04 & $100(6)$ & 100 \\
\hline & 2 & & 5 & 2787 & 0.12 & 0.19 & $75(4)$ & 100 \\
\hline & 3 & & 10 & 4138 & 0.49 & 1.14 & $71(7)$ & 85 \\
\hline & 5 & & 8 & 2017 & 0.63 & 1.30 & $83(6)$ & 100 \\
\hline & & & 7.3 & 2625 & 0.46 & 0.92 & 82 & 96 \\
\hline \multirow[t]{3}{*}{ GC } & 1 & & 7 & 2029 & 0.60 & 1.17 & $100(6)$ & 100 \\
\hline & 2 & & 10 & 5153 & 0.56 & 1.30 & $86(7)$ & 96 \\
\hline & & & 8.5 & 3591 & 0.58 & 1.24 & 93 & 98 \\
\hline
\end{tabular}

at BP was particularly striking; in 1995, only a single invertebrate (1 Eosipho canetae) among 814 collected was non-endemic, and in 1997, 7 invertebrates (5 E. canetae, 2 Cantrainea macleani) among 448 collected were non-endemic. At $\mathrm{BH}$ and $\mathrm{GC}$, the nonendemic fauna was numerically dominated by the gastropod Cataegis meroglypta.

The low species richness and high endemicity of fauna associated with these mussel beds is more similar to communities associated with hydrothermal vent mussel beds on the Mid-Atlantic Ridge than other seep habitat types. For example, Van Dover \& Trask (2000) found 13 and 17 species (excluding small fauna that would have passed through a $2 \mathrm{~mm}$ sieve such as ostracods and copepods) in mussel beds at 2 different sulfide structures on the Mid-Atlantic Ridge. By contrast, Bergquist et al. (2003) found between 21 and 40 associated heterotrophic species in each of 4 vestimentiferan aggregations collected from $\mathrm{BH}$ and $\mathrm{GC}$ on the ULS. Likewise, the proportion of endemic species
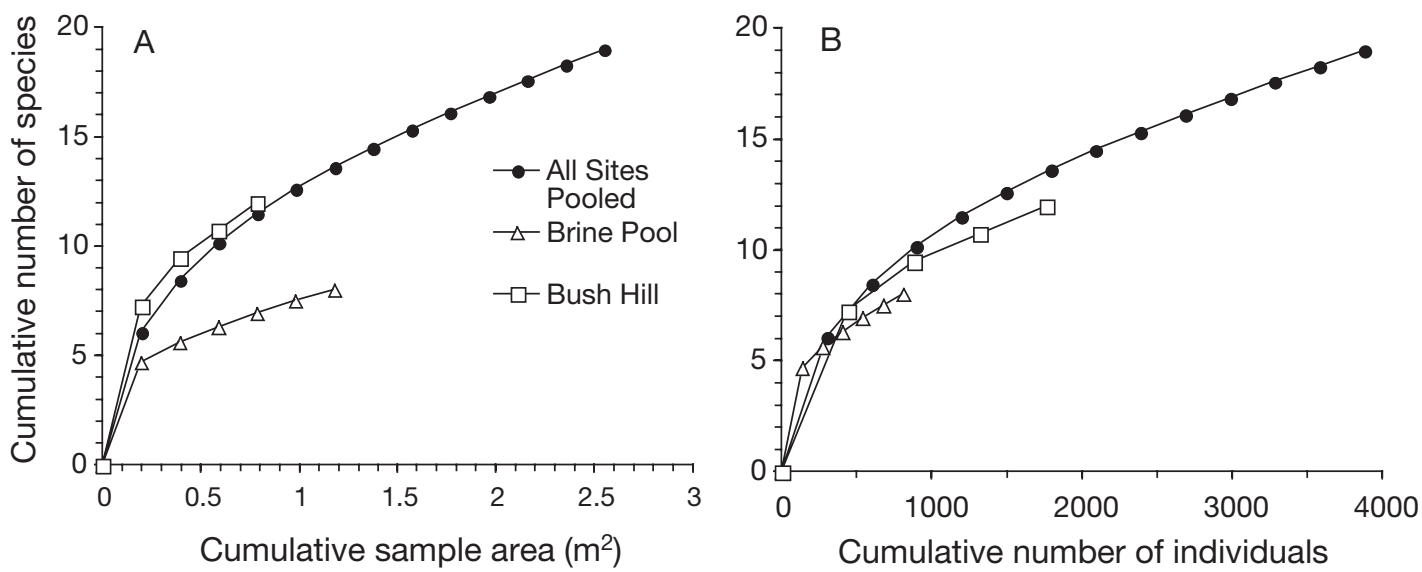

Fig. 2. Species effort curves for seep mussel beds showing the cumulative number of species versus (A) cumulative sample area and (B) cumulative number of individuals 
inhabiting hydrothermal vent environments is approximately 95\% (Tunnicliffe 1991), whereas this proportion in vestimentiferan aggregations at $\mathrm{BH}$ and $\mathrm{GC}$ was between 50 and $80 \%$ (Bergquist et al. 2003). Numerous investigators have proposed that the chemical toxicity of vent and seep habitats may limit the number of species capable of exploiting these highly productive environments (Tunnicliffe 1991, Carney 1994, Fisher 1996). Because of their dependence upon methanotrophic endosymbionts, Bathymodiolus childressi are located in areas of heavy seepage where methane is abundant, oxygen is scarce and sulfide and crude oil are often present (Kochevar et al. 1992, Nix et al. 1995). These conditions may create a microenvironment more similar in terms of chemical toxicity to that at hydrothermal vents than to that in vestimentiferan aggregations on the ULS.

In general, the brine sites (BP and GB) were characterized by higher methane concentrations, lower oxygen concentrations, lower mussel densities and higher mussel biomass than the petroleum sites (BH and $\mathrm{GC}$; Table 3). However, these characteristics varied substantially within the individual sites. At BP, mussel density and biomass decreased from the inner edge of the bed (nearest the brine) to the outer edge of the bed (furthest from the brine), and sulfide levels tended to

Table 2. Percentages of the 4 most abundant species at each seep site. A. stac.: Alvinocaris stactophila; A. stac. af.: Alvinocaris stactophila affinis; B. nat.: Bathynerita naticoidea; C. mer.: Cataegis meroglypta; M. dend: Methanoaricia dendrobranchiata; Munid.: Munidopsis sp.; P. scul.: Provanna sculpta

\begin{tabular}{|c|c|c|c|c|c|c|c|c|c|}
\hline BP-1995 & $\%$ & BP-1997 & $\%$ & GB & $\%$ & $\mathrm{BH}$ & $\%$ & GC & $\%$ \\
\hline M. dend. & 72.1 & M. dend. & 42.3 & B. nat. & 63.1 & B. nat. & 66.9 & M. dend. & 42.3 \\
\hline A. stac. & 17.3 & A. stac. & 30.6 & A. stac. & 30.3 & P. scul. & 13.8 & B. nat. & 38.4 \\
\hline B. nat. & 8.4 & B. nat. & 20.0 & Munid. & 3.3 & A. stac. & 9.5 & A. stac. & 11.8 \\
\hline A. stac af. & 1.5 & A. stac af. & 2.6 & A. stac af. & 1.6 & C. mer. & 5.8 & P. scul. & 3.0 \\
\hline
\end{tabular}

Table 3. Local habitat characteristics within the mussel beds sampled in 1995 and 1997. Methane, oxygen and sulfide concentrations are means of 2 water samples. Mussel density, total shell surface area (Shell SA) and total soft tissue ash-free dry weight (Biomass) are reported as a function of bottom area. nd = not detected. Due to impurities in the carrier gas in 1997, actual oxygen concentrations may be slightly lower and actual sulfide concentrations slightly higher than reported here; however, values should be internally consistent. Bold numbers indicate means for site characteristics

\begin{tabular}{|c|c|c|c|c|c|c|c|c|}
\hline \multirow[t]{2}{*}{ Site } & \multirow[b]{2}{*}{ No. } & \multirow[b]{2}{*}{ Position } & \multicolumn{3}{|c|}{ Environmental chemistry } & \multicolumn{3}{|c|}{ Mussel characteristics } \\
\hline & & & $\begin{array}{l}\text { Methane } \\
\left(\mathrm{mmol} \mathrm{l}^{-1}\right)\end{array}$ & $\begin{array}{c}\text { Oxygen } \\
\left(\mathrm{mmol} \mathrm{l}^{-1}\right)\end{array}$ & $\begin{array}{c}\text { Sulfide } \\
\left(\mathrm{mmol} \mathrm{l}^{-1}\right)\end{array}$ & $\begin{array}{l}\text { Density } \\
\left(\text { no. } \mathrm{m}^{-2}\right)\end{array}$ & $\begin{array}{l}\text { Shell SA } \\
\left(\mathrm{m}^{2} \mathrm{~m}^{-2}\right)\end{array}$ & $\begin{array}{l}\text { Biomass } \\
\left(\mathrm{kg} \mathrm{m}^{-2}\right)\end{array}$ \\
\hline \multicolumn{9}{|l|}{1995} \\
\hline \multirow[t]{7}{*}{$\mathrm{BP}$} & 1 & Inner & 2.748 & 0.027 & nd & 1008 & 3.92 & 2.88 \\
\hline & 2 & Inner & 0.184 & 0.125 & nd & 1273 & 4.68 & 3.06 \\
\hline & 3 & Middle & 0.139 & 0.075 & nd & 367 & 3.23 & 2.78 \\
\hline & 4 & Middle & 0.354 & 0.050 & nd & 357 & 3.32 & 2.90 \\
\hline & 5 & Outer & 2.280 & 0.027 & nd & 346 & 3.04 & 1.79 \\
\hline & 6 & Outer & 0.274 & 0.045 & 0.006 & 194 & 1.62 & 0.83 \\
\hline & & & 0.997 & 0.058 & 0.001 & 591 & 3.30 & 2.37 \\
\hline \multicolumn{9}{|l|}{1997} \\
\hline \multirow[t]{5}{*}{$\mathrm{BP}$} & 7 & Inner & 0.021 & 0.086 & nd & & & \\
\hline & 8 & Inner & 0.579 & 0.126 & 0.001 & & & \\
\hline & 9 & Middle & 1.301 & 0.111 & 0.100 & & & \\
\hline & 10 & Outer & 0.765 & 0.235 & 0.042 & & & \\
\hline & & & 0.667 & 0.140 & 0.036 & & & \\
\hline GB & 1 & & 0.306 & 0.101 & nd & 434 & 3.15 & 3.25 \\
\hline $\mathrm{BH}$ & 1 & & 0.022 & 0.057 & 0.001 & 1259 & 3.96 & 3.57 \\
\hline $\mathrm{BH}$ & 2 & & 0.010 & 0.106 & 0.004 & 575 & 1.88 & 1.45 \\
\hline $\mathrm{BH}$ & 3 & & nd & 0.226 & nd & 892 & 2.26 & 1.11 \\
\hline $\mathrm{BH}$ & 4 & & $\begin{array}{c}\text { nd } \\
\mathbf{0 . 0 0 8}\end{array}$ & $\begin{array}{c}0.276 \\
\mathbf{0 . 1 6 6 3}\end{array}$ & $\begin{array}{c}\text { nd } \\
\mathbf{0 . 0 0 1}\end{array}$ & $\begin{array}{l}2127 \\
1213\end{array}$ & $\begin{array}{l}6.98 \\
\mathbf{3 . 7 7}\end{array}$ & $\begin{array}{l}1.62 \\
\mathbf{1 . 9 4}\end{array}$ \\
\hline GC & 1 & & nd & 0.081 & nd & 2237 & 6.22 & 2.12 \\
\hline $\mathrm{GC}$ & 2 & & 0.021 & 0.129 & 0.001 & 672 & 1.43 & 0.95 \\
\hline & & & 0.011 & 0.105 & 0.001 & 1455 & 3.83 & 1.54 \\
\hline
\end{tabular}


increase toward the middle and outer portions of the bed. At $\mathrm{BH}$, oxygen concentrations, mussel densities, surface areas and biomass all varied substantially between different mussel beds.

Community characteristics were most closely correlated with differences in methane and oxygen concentrations (Table 4). Species richness, fauna density and, to a lesser extent, species diversity were significantly and negatively correlated with methane concentration; species richness and fauna density were significantly and positively correlated with oxygen concentration. The percentage of individuals within a community represented by endemics was positively correlated with mussel surface area and biomass, measures of the quantity of available structural habitat and, potentially, primary production. Because Bathymodiolus childressi are associated with areas of active seepage, the dominance of endemics in locations with the greatest mussel biomass is not surprising as both the higher productivity and toxicity is expected in these areas.

The positive relationships between species richness and fauna density and environmental oxygen concentration, suggest that oxygen availability is likely to play a key role in structuring seep mussel bed communities. The tendency of BP to host communities of lower species richness and lower fauna density may at least partially reflect the lower oxygen levels of the site. However, mussel beds at $\mathrm{BH}$ and GC are typically in close proximity to, or surrounded by, dense vestimentiferan aggregations, so the higher species richness of mussel beds at these sites could also reflect colonization of mussel beds from these aggregations or species living within the vestimentiferan aggregations foraging within the mussel beds.

CCA showed that Axis 1 explained $38.8 \%$ of the variation in community structure and Axes 2 and 3 explained an additional 10.9 and $8.7 \%$, respectively (Table 5). Oxygen and methane concentrations and, to a lesser extent, mussel biomass were the environmental variables most closely correlated with Axis 1, while sulfide and mussel surface area were those most closely correlated with Axis 2 (Table 6). Sulfide and mussel biomass were the variables most strongly correlated with Axis 3, but the magnitudes of these correlations were weak $(<0.5)$. CCA separated polychaetes, alvinocarid shrimp and gastropods along Axis 1, with polychaetes and alvinocarid shrimp (particularly Methanoaricia dendrobranchiata, Alvinocaris stactophila and Alvinocaris stactophila affinis) tending towards lower oxygen and higher methane and gastropods (particularly Provanna sculpta, Cataegis meroglypta and Cantainea macleani) tending toward higher oxygen and lower methane (Fig. 3). The endemic nerite gastropod Bathynerita naticoidea was also associated with higher oxygen and lower methane as well as higher sulfide. The predaceous non-endemic gastropod Eosipho canatae and the larger predaceous decapods (Munidopsis sp. and the Bresillid shrimp) were associated with lower sulfide and higher oxygen concentrations.

The densities of the dominant gastropod species (Bathynerita naticoidea, Cataegis meroglypta and Provanna sculpta) were positively and significantly correlated with each other (Table 7). The densities of these dominant gastropods were negatively, although not significantly, correlated with the density of the orbiniid polychaete Methanoaricia dendrobranchiata. The density of the galatheid crab Munidopsis sp. 1 was also negatively correlated with $M$. dendrobranchiata density but this relationship was not significant. Overall, polychaete density was negatively correlated with gastropod density ( $\mathrm{r}=-0.535, \mathrm{p}=0.060$ ), but no relationship was detected between crustacean density and either polychaete $(r=0.153, p=0.606)$ or gastropod densities $(r=0.297, p=0.325)$.

Table 5. Canonical Correspondence Analysis (CCA) axes summary. CV: cumulative variance

\begin{tabular}{|lccc|}
\hline & Axis 1 & Axis 2 & Axis 3 \\
\hline Eigenvalue & 0.347 & 0.097 & 0.078 \\
Variance explained (\%) & 38.8 & 10.9 & 8.7 \\
CV explained (\%) & 38.3 & 49.8 & 58.4 \\
\hline
\end{tabular}

Table 6. Bi-plot scores and coefficients of correlation of environmental characteristics in the CCA

\begin{tabular}{|lrrr|}
\hline Habitat characteristic & Axis 1 & Axis 2 & Axis 3 \\
\hline Oxygen $\left(\mathrm{mmol} \mathrm{l}^{-1}\right)$ & 0.765 & -0.197 & 0.292 \\
Methane $\left(\mathrm{mmol} \mathrm{l}^{-1}\right)$ & -0.559 & -0.262 & 0.138 \\
Sulfide $\left(\mathrm{mmol} \mathrm{l}^{-1}\right)$ & 0.112 & 0.557 & -0.460 \\
Density $\left(\mathrm{no} \mathrm{m}^{-2}\right)$ & 0.093 & -0.432 & -0.166 \\
Surface area $\left(\mathrm{m}^{2} \mathrm{~m}^{-2}\right)$ & 0.068 & -0.686 & -0.266 \\
Biomass $\left(\mathrm{g} \mathrm{m}^{-2}\right)$ & -0.409 & -0.402 & -0.379 \\
\hline
\end{tabular}




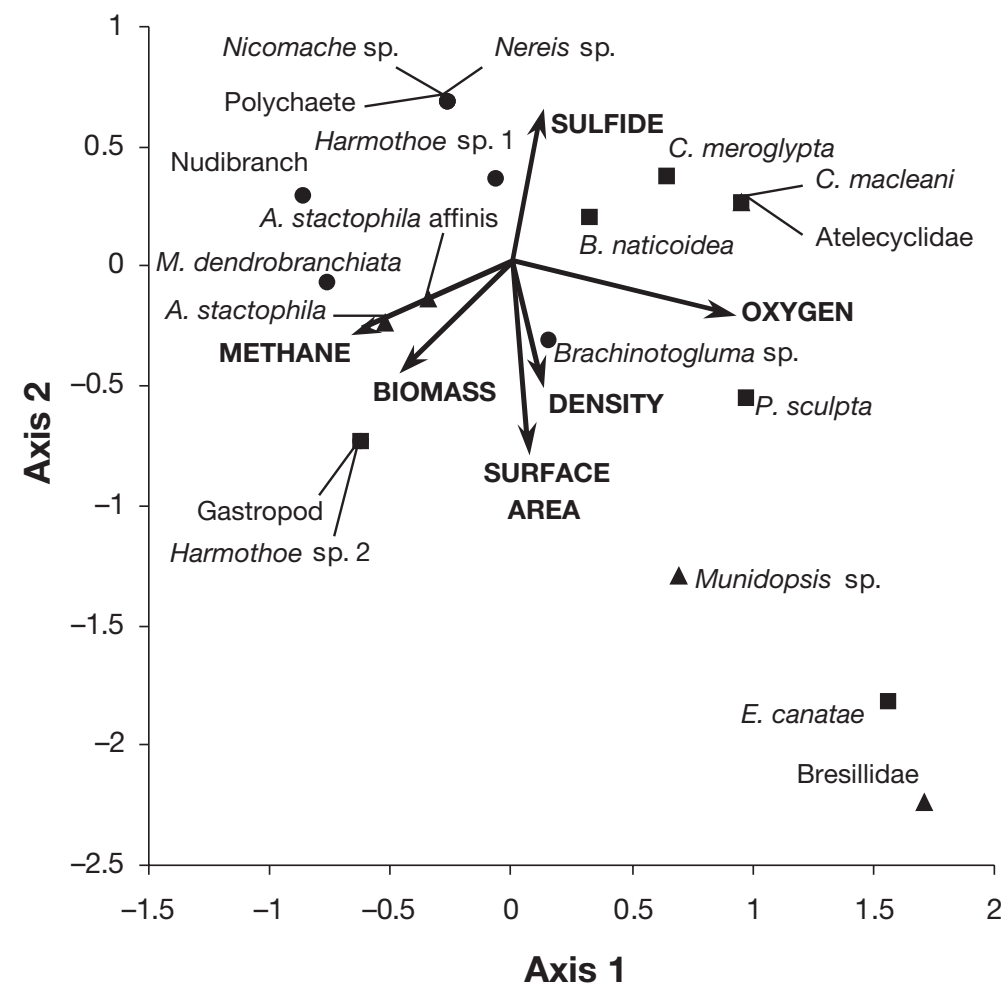

Fig. 3. Ordination graph showing the first two axes. Arrows indicate direction of increase in environmental parameters. (1): polychaetes;

(ם): gatropods; $(\boldsymbol{\Delta})$ : crustaceans. See Table 1 for full species names

The most striking patterns in species distributions were the relationships among the 3 dominant gastropods (Bathynerita naticoidea, Provanna sculpta, Cataegis meroglypta) and the orbiniid polychaete Methanoaricia dendrobranchiata. The densities of the 3 most abundant gastropod species were all positively correlated with each other, suggesting these species require a similar set of environmental conditions, but the densities of these species were negatively correlated with densities of $M$. dendrobranchiata. All 4 species most likely have similar feeding habits (bacterivory/ detritivory), so this suggests some level of resource partitioning among them. CCA indicates some separation among the three gastropods along gradients in oxygen and sulfide, but the strong positive correlations between the densities of the three gastropods suggests that any partitioning occurring between these species is occurring at small spatial scales or in ways not measured in this study.

The relationship between Methanoaricia dendrobranchiata and the three dominant gastropods may reflect differences in the microenvironments they inhabit. The gastropods were associated with mussel beds having higher oxygen and lower methane concentrations, while $M$. dendrobranchiata was

The dominant resident fauna of mussel beds varied among beds and along measured environmental gradients. Carney (1995) reported a monotonous fauna associated with mussel beds on the ULS. While examination of the presence or absence of dominant species among different sites (BP, GB, BH, GC) generally supports this conclusion, closer inspection of within and among bed patterns indicates these communities are actually quite heterogeneous. As all the fauna found in this study are mobile, this finer scale variability in individual species distributions most likely reflects their responses to physical and biological environmental characteristics that vary on small spatial (and perhaps temporal) scales. associated with lower oxygen and higher methane. $M$. dendrobranchiata possesses several functional characteristics favorable in low oxygen environments, including hypertrophied gills that provide large surface area for gaseous exchange, thin gill epithelia that reduce diffusion distances, hemoglobin with a high oxygen affinity and substantial tolerance of extended periods of anoxia (Hourdez et al. 2001, Hourdez et al. 2002). At present, it is unknown if the gastropods possess specialized anatomical or physiological characteristics favorable to low oxygen environments. The difference in the microenvironments inhabited by the gastropods and M. dendrobranchiata may reflect one or a combination of factors including habitat preferences, competitive exclusion and/or differential predation pressure.

Table 7. Results of Spearman's rank correlations between densities of the 7 most abundant species collected in mussel beds. ${ }^{*} \mathrm{p}<0.05,{ }^{* *} \mathrm{p}<0.01$

\begin{tabular}{|c|c|c|c|c|c|c|}
\hline & $\begin{array}{c}\text { Methanoaricia } \\
\text { dendrobranchiata }\end{array}$ & $\begin{array}{c}\text { Bathynerita } \\
\text { naticoidea }\end{array}$ & $\begin{array}{l}\text { Cataegis } \\
\text { meroglypta }\end{array}$ & $\begin{array}{l}\text { Provanna } \\
\text { sculpta }\end{array}$ & $\begin{array}{l}\text { Alvinocaris } \\
\text { stactophila }\end{array}$ & $\begin{array}{c}\text { Alvinocaris } \\
\text { stactophila af }\end{array}$ \\
\hline Bathynerita naticoidea & -0.522 & & & & & \\
\hline Cataegis meroglypta & -0.296 & $0.800^{* *}$ & & & & \\
\hline Provanna sculpta & -0.350 & $0.833^{* *}$ & $0.804^{* *}$ & & & \\
\hline Alvinocaris stactophila & 0.162 & 0.292 & 0.087 & 0.425 & & \\
\hline Alvinocaris stactophila af. & 0.260 & 0.166 & 0.159 & 0.472 & $0.886^{* *}$ & \\
\hline Munidopsis sp. & -0.527 & 0.287 & 0.109 & 0.488 & 0.358 & 0.307 \\
\hline
\end{tabular}


Acknowledgements. Special thanks are due to Harbor Branch Oceanographic Institution and the captains, pilots and crew of the RV Seward Johnson and the DSRV 'Johnson Sea Link'. This work was supported by the Mineral Management Service project RFP-6899 and the Minerals Management Service, Gulf of Mexico Regional OCS Office through contract number 1435-01-96-CT30813 and the NOAA National Undersea Research Program at the University of North Carolina, Wilmington. We would also like to thank E. B. Szalai, E. R. McMullin and A. Olaharski for their assistance at sea and three anonymous reviewers for their comments on previous versions of this manuscript. M. J. van Horn and K. M. Scott provided critical technical assistance with water sample analyses.

\section{LITERATURE CITED}

Bergquist DC, Ward T, Cordes EE, McNelis Tand 5 others (2003) Community structure of vestimentiferan-generated habitat islands from Gulf of Mexico cold seeps. J Exp Mar Biol Ecol 289:197-222

Bergquist DC, Fleckenstein C, Szalai EB, Knisel J, Fisher CR (2004) Environment drives physiological variability in the cold seep mussel Bathymodiolus childressi. Limnol Oceanogr 49:706-715

Brooks JM, Kennicutt II MC, MacDonald IR, Wilkinson DL, Guinasso NLJ, Bidigare RR (1989) Gulf of Mexico hydrocarbon seep communities, part IV: descriptions of known chemosynthetic communities. Proc Offshore Technol Conf, OTC 5954:663-667

Carney RS (1994) Consideration of the oasis analogy for chemosynthetic communities at Gulf of Mexico hydrocarbon vents. Geo Mar Lett 14:149-159

Carney RS (1995) Sessile macrofauna and megafauna at mussel beds. In: MacDonald IR, Schroeder WW, Brooks JM (eds) Northern Gulf of Mexico chemosynthetic ecosystems study final report. Prepared for Minerals Management Services under contract 14-35-0001-30555

Cary SC, Fisher CR, Felbeck H (1988) Mussel growth supported by methane as sole carbon and energy source. Science 240:78-80

Chazdon RL, Colwell RK, Denslow JS, Guariguata MR (1998) Statistical methods for estimating species richness of woody regeneration in primary and secondary rain forests of NE Costa Rica. In: Dallmeier F, Comiskey JA (eds) Forest biodiversity research, monitoring and modeling: Conceptual background and Old World case studies. Parthenon Publishing, Paris, p 285-309

Childress JJ, Fisher CR (1992) The biology of hydrothermal vent animals: physiology, biochemistry, and autotrophic symbioses. Oceanogr Mar Biol Ann Rev 30:337-441

Childress JJ, Arp AJ, Fisher CR (1984) Metabolic and blood characteristics of the hydrothermal vent tube worm Riftia pachyptila. Mar Biol 83:109-124

Childress JJ, Fisher CR, Brooks JM, Kennicutt II MC, Bidigare R, Anderson A (1986) A methanotrophic marine molluscan symbiosis: mussels fueled by gas. Science 233:1306-1308

Colwell RK (2004) EstimateS: Statistical estimation of species richness and shared species from samples. Version 7. Users guide and application published at: http://purl. oclc.org/estimates

Fisher CR (1996) Ecophysiology of primary production at deep-sea vents and seeps. Biosys Ecol Ser 11:313-336
Gilboa-Garber N (1971) Direct spectophotometric determination of inorganic sulfide in biological materials and in other complex mixtures. Biochem 43:129-133

Hourdez S, Frederick L, Schernecke A, Fisher CR (2001) Functional respiratory anatomy of a deep-sea orbiniid polychaete from the Brine Pool NR-1 in the Gulf of Mexico. Invert Zool 120:29-40

Hourdez S, Weber RE, Green BN, Kenney JM, Fisher CR (2002) Respiratory adaptations in a deep-sea orbiniid polychaete from Gulf of Mexico brine pool NR-1: metabolic rates and hemoglobin structure/function relationships. J Exp Biol 205:1669-1681

Kochevar R, Childress JJ, Fisher CR, Minnich E (1992) The methane mussel: roles of symbiont and host in the metabolic utilization of methane. Mar Biol 112:389-401

MacDonald IR (1998) Stability and change in Gulf of Mexico chemosynthetic communities: Interim report. Prepared for the Department of the Interior, Minerals Management Service, Gulf of Mexico OCS Region, p 409

MacDonald IR, Boland GS, Baker JS, Brooks JM, Kennicutt II MC, Bidigare RR (1989) Gulf of Mexico chemosynthetic communities II: spatial distribution of seep organisms and hydrocarbons at Bush Hill. Mar Biol 101:235-247

MacDonald IR, Reilly II JF, Guinasso Jr NL, Brooks JM, Carney RS, Bryant WA, Bright TJ (1990) Chemosynthetic mussels at a brine-filled pockmark in the northern Gulf of Mexico. Science 248:1096-1099

MacDonald IR, Buthman D, Sager WW, Peccini MB, Guinasso Jr NL (2000) Pulsed oil discharge from a mud volcano. Geology 28:907-910

MacDonald IR, Sager WW, Peccini MB (2003) Association of gas hydrate and chemosynthetic fauna in mounded bathymetry at mid-slope hydrocarbon seeps: Northern Gulf of Mexico. Mar Geol 198:133-158

Nix ER, Fisher CR, Vodenichar J, Scott KM (1995) Physiological ecology of a mussel with methanotrophic endosymbionts at three hydrocarbon seep sites in the Gulf of Mexico. Mar Biol 122:605-617

Palmer MW (1993) Putting things in even better order: the advantages of canonical correspondence analysis. Ecology 74:2215-2230

Sarrazin J, Juniper SK (1999) Biological characteristics of a hydrothermal edifice mosaic community. Mar Ecol Prog Ser 185:1-19

Sibuet M, Olu K (1998) Biogeography, biodiversity and fluid dependence of deep-sea old-seep communities at active and passive margins. Deep-Sea Res II 45:517-567

Smith EB, Scott KM, Nix ER, Korte C, Fisher CR (2000) Growth and condition of seep mussels (Bathymodiolus childressi) at a Gulf of Mexico brine pool. Ecology 81: 2392-2403

Streams ME, Fisher CR, Fiala-Medioni A (1997) Methanotrophic symbiont location and fate of carbon incorporated from methane in a hydrocarbon seep mussel. Mar Biol 129:465-476

Tunnicliffe V (1991) The biology of hydrothermal vents: ecology and evolution. Oceangr Mar Biol Annu Rev 29:319-407

Van Dover CL (2002) Community structure of mussel beds at deep-sea hydrothermal vents. Mar Ecol Prog Ser 230: $137-158$

Van Dover CL, Trask JL (2000) Diversity at deep-sea hydrothermal vents and intertidal mussel beds. Mar Ecol Prog Ser 195:169-178 
Appendix 1. Fauna associated with 17 collections from Bathymodiolus childressi beds. Included is the endemic status (E: endemic, known only from seep sites; N: non-endemic, known from the background fauna of the upper Louisiana slope) of each species. BP, BH, GC, CB: sampled sites

\begin{tabular}{|c|c|c|c|c|c|c|c|c|c|c|c|c|c|c|c|c|c|c|}
\hline \multirow[t]{2}{*}{ Taxon } & \multirow{2}{*}{$\begin{array}{l}\text { Endemic } \\
\text { status }\end{array}$} & \multirow{2}{*}{$\mathrm{C}$} & \multirow[b]{2}{*}{2} & \multicolumn{2}{|c|}{ - BP 1995} & \multirow[b]{2}{*}{5} & \multirow[b]{2}{*}{6} & \multicolumn{4}{|c|}{$\longrightarrow$ BP $1997-$} & \multicolumn{4}{|c|}{$\longrightarrow \mathrm{BH} \longrightarrow$} & \multicolumn{2}{|c|}{ GC } & \multirow{2}{*}{$\begin{array}{c}\mathrm{GB} \\
1\end{array}$} \\
\hline & & & & 3 & 4 & & & 7 & 8 & 9 & 10 & 1 & 2 & 3 & 4 & 1 & 2 & \\
\hline \multicolumn{19}{|l|}{ Annelida } \\
\hline \multicolumn{19}{|l|}{ Polynoidae } \\
\hline Branchinotoglumina sp & E & 0 & 1 & 0 & 0 & 0 & 0 & 0 & 0 & 0 & 0 & 0 & 0 & 0 & 0 & 0 & 0 & 0 \\
\hline Harmothoe sp.1 & & 0 & 0 & 0 & 0 & 0 & 0 & 0 & 1 & 0 & 1 & 0 & 0 & 1 & 0 & 1 & 2 & 0 \\
\hline Harmothoe sp.2 & & 0 & 0 & 0 & 0 & 0 & 0 & 0 & 0 & 0 & 3 & 0 & 0 & 0 & 0 & 0 & 0 & 1 \\
\hline \multicolumn{19}{|l|}{ Orbiniidae } \\
\hline $\begin{array}{l}\text { Methanoaricia } \\
\text { dendrobranchiata }\end{array}$ & $\mathrm{E}$ & 203 & 140 & 2 & 141 & 51 & 47 & 192 & 0 & 0 & 0 & 1 & 0 & 0 & 0 & 114 & 387 & 0 \\
\hline \multicolumn{19}{|l|}{ Nereididae } \\
\hline \multirow{2}{*}{\multicolumn{19}{|c|}{ Maldanidae }} \\
\hline & & & & & & & & & & & & & & & & & & \\
\hline Nichomache sp. & & 0 & 0 & 0 & 0 & 0 & 0 & 0 & 0 & 0 & 0 & 0 & 0 & 0 & 0 & 0 & 1 & 0 \\
\hline Unidentified Polychaete & & 0 & 0 & 0 & 0 & 0 & 0 & 0 & 0 & 0 & 0 & 0 & 0 & 0 & 0 & 0 & 2 & 0 \\
\hline \multicolumn{19}{|l|}{ Mollusca } \\
\hline $\begin{array}{l}\text { Unidentified nudibranch } \\
\text { Neritidae }\end{array}$ & & 1 & 0 & 0 & 0 & 0 & 1 & 0 & 0 & 0 & 0 & 0 & 0 & 0 & 0 & 0 & 0 & 0 \\
\hline $\begin{array}{l}\text { Bathynerita naticoidea } \\
\text { Turbinidae }\end{array}$ & $\mathrm{E}$ & 13 & 5 & 16 & 6 & 15 & 13 & 1 & 11 & 46 & 33 & 136 & 440 & 419 & 182 & 161 & 294 & 77 \\
\hline $\begin{array}{l}\text { Cantrainea macleani } \\
\text { Trochiidae }\end{array}$ & $\mathrm{N}$ & 0 & 0 & 0 & 0 & 0 & 0 & 0 & 2 & 0 & 0 & 0 & 0 & 2 & 0 & 0 & 0 & 0 \\
\hline $\begin{array}{l}\text { Cataegis meroglypta } \\
\text { Buccinidae }\end{array}$ & $\mathrm{N}$ & 0 & 0 & 0 & 0 & 0 & 0 & 0 & 0 & 0 & 0 & 0 & 2 & 99 & 1 & 0 & 35 & 0 \\
\hline $\begin{array}{l}\text { Eosipho canetae } \\
\text { Provannidae }\end{array}$ & $\mathrm{N}$ & 0 & 0 & 0 & 0 & 0 & 1 & 0 & 4 & 1 & 0 & 0 & 1 & 2 & 23 & 0 & 0 & 0 \\
\hline Provanna sculpta & $\mathrm{E}$ & 0 & 0 & 0 & 0 & 0 & 0 & 0 & 0 & 0 & 0 & 11 & 9 & 125 & 97 & 9 & 27 & 0 \\
\hline Unidentified gastropod & & 0 & 0 & 0 & 0 & 0 & 0 & 0 & 0 & 0 & 0 & 0 & 0 & 0 & 0 & 0 & 0 & 1 \\
\hline \multicolumn{19}{|l|}{ Arthropoda } \\
\hline \multicolumn{19}{|l|}{ Alvinocarididae } \\
\hline Alvinocaris stactophila & $\mathrm{E}$ & 68 & 17 & 27 & 10 & 16 & 2 & 84 & 33 & 6 & 16 & 107 & 4 & 29 & 27 & 47 & 93 & 37 \\
\hline $\begin{array}{l}\text { Alvinocaris stactophila } \\
\text { affinis }\end{array}$ & $\mathrm{E}$ & 6 & 3 & 1 & 1 & 0 & 1 & 1 & 11 & 0 & 0 & 8 & 0 & 5 & 2 & 3 & 6 & 2 \\
\hline Atelecyclidae & & 0 & 0 & 0 & 0 & 0 & 0 & 0 & 1 & 0 & 0 & 0 & 0 & 1 & 0 & 0 & 0 & 0 \\
\hline Bresilliidae & & 0 & 0 & 0 & 0 & 0 & 0 & 1 & 0 & 0 & 0 & 0 & 0 & 0 & 2 & 0 & 0 & 0 \\
\hline \multicolumn{19}{|l|}{ Galatheidae } \\
\hline Munidopsis sp. 1 & $\mathrm{E}$ & 0 & 0 & 0 & 2 & 0 & 0 & 4 & 0 & 1 & 2 & 5 & 0 & 3 & 16 & 1 & 0 & 4 \\
\hline
\end{tabular}

Editorial responsibility: Otto Kinne (Editor-in-Chief), Oldendorf/Luhe, Germany
Submitted: June 11, 2004; Accepted: January 27, 2005

Proofs received from author(s): May 2, 2005 